\title{
Developmental Governance
}

\author{
Jan-Erik Lane \\ University of Geneva, Geneva, Switzerland \\ Email: janeklane@gmail.com
}

How to cite this paper: Lane, J.-E. (2019). Developmental Governance. Open Journal of Political Science, 9, 624-630.

https://doi.org/10.4236/ojps.2019.94038

Received: August 22, 2019

Accepted: September 27, 2019

Published: September 30, 2019

Copyright (C) 2019 by author(s) and Scientific Research Publishing Inc. This work is licensed under the Creative Commons Attribution International License (CC BY 4.0).

http://creativecommons.org/licenses/by/4.0/

\begin{abstract}
The World Bank now launches the concept of developmental governance as commitment, coordination and cooperation. When unpacked, development governance is no clearer than the concept of development administration. It is true that countries need development to improve living conditions for their citizens, but development includes more than governance or good governance.
\end{abstract}

\section{Keywords}

Development, Governance, Rule of Law, Distribution, Redistribution, Piketty, Rubinstein Model

\section{Introduction}

From the title, one may anticipate that this publication will connect with the old discussion about the possibility of government governing economic growth. As is well known, there was a long debate about import substitution as against export orientation as the chief policy to stimulate development. On the one hand the adherence of the developmental state, like Prebisch and Myrdal, and on the other hand, the marketers like Friedman and Bhagvathi. Today, the idea of an open economy operating under equal rules of the WTO is accepted. What the World Bank now suggests is to identify the mechanism that supports stable economic goals arguing that political elites must develop more of commitment, coordination and cooperation not only among themselves but also with social and economic elites. Thus, the World Bank recommends changes that improve rule of law: accountability, equality of power and resources as well as policy responsibility.

\section{What Is Developmental Governance?}

One may remind of the debate concerning developmental administration. It was 
at first a popular phrase, signaling a new discipline analyzing development in the Third World in combination with practical recommendations to policies (Levi-Faur, 2012; Bevir, 2013). Gant describes it as follows:

"The term development administration came into use in the 1950s to represent those aspects of public administration and those changes in public administration, which are needed to carry out policies, projects, and programs to improve social and economic conditions (Gant, 2006)".

But it later became obvious that development administration was merely a phrase, hiding the lack of substantial knowledge about the implementation of developmental goals. Perhaps the same will occur with developmental governance. It seems, indeed, difficult to talk about development governance without entering the theory of economic growth. Development or socio-economic development is usually considered as the outcome of processes of economic growth, emphasizing the impact on education, health, housing and employment. Developmental Governance would by implication be made up of the policies that enhance education, health, housing and employment. Perhaps developmental governance is related to the concept of "developmental state" (Wade, 2018). The World Bank Report (World Bank, 2017) claims that three factors are crucial for the successful implementation of such developmental goals: commitment, coordination, and cooperation. This follows the concentration of the World Bank on the role of elites in societies, arguing that these people decide whether positive development is achievable or not.

The World Bank report (World Bank, 2017) speaks of "governance" and alternatively "governance with rule of law". These phrases do not have the same connotation or denotation as not all countries have rule of law despite being governed. Perhaps the World Bank would reply to this criticism that governance based on commitment, coordination, and cooperation amounts to governance with rule of law, but this is hardly the case. Developmental governance has taken place in China as well as in Japan, although the models of policymaking and implementation have been vastly different. Let me discuss the three factors of governance a little more closely.

I will use the concept of principal-agent relationships to clarify the problematics of developmental governance. Below, the population of a country constitutes the principal whereas the Government and its bureaucracy make up the development agents together with internationally funded aid agents, and the question is, of course, how the agents can be given incentives to work for the development of the country and its people.

\section{Governance as Commitment}

From the fact that the elites in society, e.g. Nigeria, South Africa or Brazil, state that they adhere to the idea of development, it does not imply that there will be genuine progress. It may all be a matter of propaganda, including lies. It is difficult to tell what a person is really committed to as guile often occurs among op- 
portunistic elites; however, it is not even true that real commitment to development is successful, i.e. results in developmental advances. For instance, economic forecasts about the pace of development tend to be optimistic or even opportunist. In well-ordered societies, the commitment to economic growth is almost like a spontaneous order in Hayek's sense. When an economic depression is predicted, various countermeasures are taken, or automatic stabilizers enter in action. When companies fail, management is replaced. When exports fall, the currency is devalued or depreciated.

Yet, one understands the emphasis on development as commitment by the World Bank, given the many experiences of rulers who destroyed their own nation by self-centered activities-e.g. former Zimbabwe leader Robert Mugabe or former Iraqi president Saddam Hussein.

\section{Governance as Coordination}

"Coordination" is an opaque word that could take on different meanings. What kind of coordination is involved in developmental governance? Could it be macroeconomic coordination of the entire economy as in classical Keynesianism? Or does it involve merely coordination between the natural Governments and sub-level Governments? In fact, coordination sounds nice but is not easily achieved. One telling example is the Greek economic crisis where the EU imposed sharp cutbacks in Greek public spending while certain Greek economists claimed that these policies of austerity only served to worsen the crisis.

\section{Governance as Cooperation}

An essential component of development is economic growth. Only by having access to new resources can new policies be implemented. There are various opinions on what advances economic growth, leading to clashes of opinion or even direct conflict between capital and labor, or between political parties. Confrontation in democratic politics has not hindered economic growth in well-ordered societies. Political elites may in perfect cooperation choose the wrong growth policy. In a developmental process that lasts many years leading to enhanced prosperity, conflicts of the distribution of wealth are bound to occur. Where is the augmentation of national wealth going to end up-in the private or the public sector? Let us look at Thomas Piketty's argument (Piketty 2013, 2015).

\section{Piketty and Rubinstein}

Piketty has received worldwide attention for his theory that capital remuneration now tends to grow faster than labor income. He writes:

"I can now present the first fundamental law of capitalism, which links the capital stock to the flow of income from capital. The capital/income ratio $\beta$ is related in a simple way to the share of income from capital in national income, denoted $\alpha$. The formula is 


$$
\alpha=r \times \beta
$$

where $r$ is the rate of return of capital.

For example, if $\beta=600 \%$ and $\mathrm{r}=5 \%$, then $\alpha=r \times \beta=30 \%$ (Piketty, 2015: $\mathrm{p}$. 42).

The attention given to his argument about the distribution of national income in many countries and over time has been much debated, because equality as a value in policies and for society has been underlined in modern political theory and economic philosophy (Rawls, 1971; Sen, 2009; Atkinson, 1983; Barry, 1995). It came almost like a shock for politicians that inequality was on the increase to the advantage of capital owners.

Now, Piketty has two main ideas:

1) Capital remuneration is its percentage share time's total capital assets as a percentage of national income,

2) Economic equality can only advance when economic growth is substantial.

It is argument 2) that is the key to his theory that development up to World War I resulted in huge economic disparities, whereas much of the 20th century witnessed higher equality. From 1980 and onwards, the share of capital in national income is again rising, which is why Piketty proposes inter alia a global progressive tax on capital income.

It must be clarified that he never explains why we have seen this history of decreasing, increasing and then again decreasing equality. Surely, development not only is cooperation but also provides many issues of conflict, especially with regards to distribution of prosperity. Let us not forget that distribution was a main focus for the classical economists. I suggest that the struggle between capital and labor over the division of yearly national income should be analyzed as a negotiation game with the help of the Ariel Rubinstein model (Rubinstein, 1982). Negotiation games have several Nash equilibria which require only that the two parties manage to divide the whole cake. Thus, a lockout from the side of capital or strikes on the part of labor signals a coordination failure. One has discussed several solutions to the negotiation game, e.g. equality of outcomes, maximization of the share of least advantage, and the maximization of total output. Rubinstein showed that the likely Nash-equilibrium depends on the patience of the players in rounds of negotiation, and this outcome will not necessarily be equality. In well-ordered societies, the labor share of national income tends to be larger income than for capital, yet it is alarming that Piketty has discovered that labor's share is shrinking, and capital's share is rising. I would argue that this reflects changes in negotiation strength. Labor has become less willing to accept the losses from strikes, reducing their bargaining patience. The internationalization of capital movements and the globalization of the World economy have made capital less vulnerable to strikes and more capable of threatening labor with lockout and similar actions. In the interwar years and after WWII, labor was much stronger both politically and in trade unions. The fall in trade union membership rates has been rather drastic, making them less powerful in negoti- 
ations on collective bargaining agreements. Finally, it seems that Piketty bypasses redistribution in kind, i.e. when government through public policy offers subsidized services to the population (education, health care and social benefits). For instance, many European nations provide tertiary studies free of charge, benefitting especially wage earners and their families.

Instead, Piketty's works analyze the historical evolution of the quantities $r$ (capital share of national wealth) and $g$ (economic growth). He states:

"When the rate of return on capital exceeds the rate of growth of output and income, as it did in the nineteenth century and seems quite likely to do again in the twenty-first, capitalism automatically generates arbitrary and unsustainable inequalities that radically undermines the meritocratic values on which democratic societies are based (Piketty, 2013)." The consequences of an $r$ value greater than for several nations as well as globally are examined in several enquiries. However, Piketty fails to explain the capital advances that come with neo-liberalism; he merely calls for more governmental intervention in the form of global redistribution using capital taxes. Yet the division of national wealth between capital and labor can be explained as a rational adaptation to bargaining strength. Wage settlements including collective agreements are determined by the negotiating strength of capital and wage earners, respectively. Let $x$ connotate the share of capital and $y$ the share of labor. Then by definition

$$
x+y=1
$$

Capital proposes $x 1$ or $x 2$ while labor offers $y 1$ or $y 2$. The patience of the players determines the outcome according to various discount rates, $\delta 1$ and $\delta 2$, Rubinstein states:

$$
x=\left(\frac{1-\delta 2}{1-\delta 1 \delta 2}\right)
$$

and

$$
y=1-x
$$

If the distribution of national income between the two players (capital owners/wage earners) depends on rational choice concerning bargaining power and Piketty is correct that $r$ values are rising, the possibility of global redistribution policies seems unlikely.

Neoclassical Economic Growth and Development

It is interesting to observe that the World Bank has dramatically enlarged its vision of development from a narrow focus on economic growth to an emphasis on the attitudes towards development among elites, whether they are political, social, religious or economic. Another way of stepping outside of the narrow theory of balanced economic growth-proportionate increase in capital and labor, innovations or technical advances-is to focus on the role of institutions in fostering development or commitment, coordination and cooperation. It draws my attention that the study of developmental processes has recently come to include not only colonial experiences but also widespread diseases or long-term 
exposure to lethal insects, e.g. malaria. We are only waiting for an inquiry into the effects of global warming on development.

Nevertheless, economic growth remains a necessary part of the story of a successful developmental process, and economic growth always consists of increases in capital, labor and innovation (Solow, 2001) only when output increases can a government find the resources to spend on services to its population. And here the market economy is central. Case example Vietnam: After the tragic and pointless Vietnam War, Hanoi introduced command economy in the entire country and the outcome was perfectly Hayekian as mass poverty and economic stagnation. With the turn to the institutions of market economy in the 1990s, they have recovered quickly and become an important player in the ASEAN.

When a country is integrated into the global economy, its potential for development increases. Respect for market institutions is an integral part of the rule of law. The 20th century harbors the story of the competition between two systems: Soviet socialism vs. Chicago-style capitalism. The outcome was the compromise of the welfare state in well-ordered societies. The model of the mixed economy is highly relevant for third world nations or rapidly developing countries, e.g. South Korea, and public spending has a fundamental egalitarian impact which Piketty does not really emphasize enough. Welfare state services, even when small in size, create vital job opportunities, especially for women in less affluent nations.

\section{Conclusion}

French Economist Jean-Baptiste Say stated that developmental advances for a state can only come through increased production of goods and services: Supply determines Demand. Say's law holds also for any development strategy. To reduce poverty and lift people out of dismal living conditions, they must have employment and receive public services, hopefully free. Cooperation, Coordinate and Commitment among elites could push development forward, but it is no universal panacea. Neither the attitudes nor the institutions of World Bank developmental governance offer a necessary condition for developmental success. Only positive and balanced economic growth makes developmental governance and good governance possible.

It is not an exaggeration to say that equality is almost as politized as the environment. Many political theories and moral philosophers claim that the concept of justice in well-ordered societies requires more parity in terms of income and life opportunities. The politics of distribution and redistribution will become more relevant in the years to come. National income (GNP) is divided between owners of capital, wage earners and State entities. The state may redistribute to the advantage of labor, making statements about increasing inequalities uncertain (Musgrave, 1959).

Development is impossible without a prolonged period of economic growth, involving more work, new investments and technological advances (Bhagwati, 
2007). If the three factors of the World Bank-cooperation, coordination, commitment-support economic growth then so much for the better. Distributional and re-distributional matters will loom large in a development process. Governance plays a big role in redistribution, e.g. when government offers vital services free of charge. In fact, redistribution may reduce an inegalitarian division of the national income, as has been the case in the Scandinavian welfare state with heavily subsidised or free education, healthcare and social care. But poor countries can only develop by raising output in accordance with Say's law that supply creates demand. Any and all economic production must from now be governed by Greta Thunberg maxim: minimise ecological impact!

\section{Conflicts of Interest}

The author declares no conflicts of interest regarding the publication of this paper.

\section{References}

Atkinson, A. B. (1983). The Economics of Inequality. Oxford: Clarendon Press.

Barry, B. (1995). Justice as Impartiality. Oxford: Clarendon Press.

Bevir, M. (2013). The Sage Handbook of Governance. London: Sage Publications.

Bhagwati, J. (2007). In Defense of Globalization. Oxford: Oxford University Press.

Gant, G. F. (2006). The Concept of Development Administration. Comparative Public Administration (Research in Public Policy Analysis and Management), 257-285.

Levi-Faur, D. (2012). The Oxford Handbook of Governance. Oxford: Oxford University Press.

Musgrave, R.A. (1959). The Theory of Public Finance. New York: McGraw-Hill.

Piketty, T. (2013). Capital in the Twenty-First Century. Cambridge, Massachusetts: Harvard University Press.

Piketty, T. (2015). The Economics of Inequality. Cambridge, Massachusetts: Belknap Press.

Rawls, J. (1971). A Theory of Justice. Cambridge, Massachusetts: Belknap Press.

Rubinstein, A. (1982). Perfect Equilibrium in a Bargaining Model. Econometrica, 50, 97-109.

Sen, A. (2009). The Idea of Justice. Cambridge, Massachusetts, Harvard University Press.

Solow, R. (2001). Growth Theory: An Exposition. New York: Oxford University Press.

Wade, R.H. (2018). The Developmental State: Dead or Alive? Development and Change, 49, 518-546.

World Bank (2017). World Development Report 2017: Governance and the Law. Washington, D.C., World Bank. 